Silva, C.C.V.' da; Mangrich-Rocha, R.M.V.'; Moreira, J.L.'; Thoms, E.'

\section{0 - Avaliação do perfil hematológico e bioquímico do sangue de cão com Ehrlichia platys realizada no laboratório de análises clínicas da Unidade Hospitalar para Animais de Companhia (UHAC) da PUC-PR. Relato de caso}

1- Pontifícia Universidade Católica do Paraná (PUC-PR) - Centro de Ciências Agrárias e Ambientais, São José dos Pinhais-PR

A Ehrlichia platys é a única entre as espécies do gênero Ehrlichia que parasita plaquetas ao invés de leucócitos, e a enfermidade resultante da infecção é denominada trombocitopenia cíclica em cães (HARVEY, 1978). Segundo descrito em literatura (BREITSCHWERDT, 1997; HARVEY, 1978), dentre as anormalidades clinico patológicas podem estar presentes: algum grau de trombocitopenia, anemia normocitica normocrômica suave a moderada, hipoalbuminemia, aumento da fosfatase alcalina (FA) e da alanina-aminotransferase (ALT) além de proteinúria. O presente relato tem por objetivo descrever os perfis hematológicos e bioquímicos do sangue de um cão, fêmea, SRD, de oito meses de idade que foi levado por seu proprietário ao serviço de Medicina Veterinária do ProAção (Programa de Ação Comunitária e Ambiental) da PUC-PR no município de Tijucas do Sul - PR, onde foi avaliado em uma consulta clínica. Durante a anamnese e exame clínico foram constatados sinais de depressão, apatia, prostração, normotermia, hiporexia à anorexia há 15 dias, emaciaçào e sangramento espontâneo na orelha sete dias antes da consulta. A suspeita clínica inicial foi de babesiose. Foram encaminhadas amostras de sangue total com anticoagulante (EDTA) e de soro em tubo de vácuo com ativador de coágulo para o Laboratório de Análises Clínicas do UHAC da PUC-PR, campus São José dos Pinhais. Na análise laboratorial, os resultados obtidos no hemograma foram os seguintes: eritrócitos $7.320 .000 / \mathrm{ml}$; hemoglobina $-14,78 \mathrm{~g} / \mathrm{dl}$; hematócrito - 38\% leucócitos totais 12.150 / $\mathrm{ml}$; neutrófilos segmentados - $1.194 / \mathrm{ml}$, linfócitos $4.738,5 / \mathrm{ml}$, eosinófilos $1.579,5 / \mathrm{ml}$, monócitos $3.766,5 / \mathrm{ml}$ e neutrófilos bastonetes $121,5 / \mathrm{ml}$. As análises bioquímicas demonstraram valores de uréia e creatinina normais comparados aos de referência descritos em literatura e de alanina-aminotransferase (ALT) apresentou-se com valor de 11,75 UI/ $\mathrm{L}$, abaixo dos valores de referência descritos em literatura, contradizendo HARVEY, 1978. Durante a contagem diferencial de leucócitos, no esfregaço sangǘneo, corado com corante do tipo Romanowsky foram observadas inclusões plaquetárias basofílicas, redondas e ovaladas envoltas por uma membrana e mórulas basofilicas nas plaquetas - estruturas compativeis com Ehrlichia platys; discreta anisocitose e policromatofilia,; linfócitos reativos; plaquetas macrocíticas e em número normal à aumentadas por campo, compatível com a normalidade plaquetária que ocorre em umas das fases descritas por HARVEY, 1978, na infecçào por Elrrlichia platys. Por não haver relato prévio da presença de Ehrlichia platys conhecidos na região, o interesse clínico patológico e epidemiológico dos pesquisadores motivou o presente relato de caso. 